\title{
Model of Early Support of Child Development in Poland
}

\author{
Anna Katarzyna Czyż \\ Faculty of Pedagogy, Pedagogical University of Cracow, Poland
}

Copyright(C2018 by authors, all rights reserved. Authors agree that this article remains permanently open access under the terms of the Creative Commons Attribution License 4.0 International License

\begin{abstract}
The development of a child, especially a child with a disability, is conditional upon the initiation of rehabilitation measures immediately after the problem has been identified. The quality of the reaction is conditioned by the functioning of the therapeutic team. The main purpose of the research was the diagnosis of early support system for child development in Poland. The research was based on the model of the functioning of teams by Twardowski. 44 teams took part in the study. The results show that depending on the area of the study, specific to the model (multi, inter or trans-disciplinary) solutions are applied. Areas most closely related to the multidisciplinary model are: responsibility for the realization of the program, cooperation with other entities, cooperation with other entities and selection of team members' directives for functioning (functioning). Areas most closely related to the interdisciplinary model are: carrying out diagnosis, cooperation with parents' development of work program and means of communication within the team. Area most closely related to the transdisciplinary model is: content assumptions. Areas most closely related to inter and transdisciplinary are: development of work program and team development. Research allows diagnosing the condition and determining the direction of development of the teams.
\end{abstract}

Keywords Early Support System, Intervention, Children, Therapy

\section{Introduction}

Every child needs support in development, regardless of them being disabled or not. Children whose development from the start is not proper or was for some reason halted, require specific, unique so to speak, specialized support so that they can develop their full potential and achieve self-reliance in adult life. In Europe, institutionalized forms of support for the youngest children at risk for biopsychosocial dysfunctions or not developing properly dated back to the previous century; however on a large scale, they began their operations in the beginning of the 20 th century. The main reason for transformations was the growing social needs, including an increasing number of children requiring special approach in terms of diagnosing and rehabilitating. In order to formulate common for all partner countries directions of changes in systems of early childhood development support and early intervention, almost 30 years of experience of work and cooperation between therapists, parents and children have been taken into account. Today, attention is mostly paid to the quality of interactions connected to the boundlessness and proximity of access, speed and adequacy of support. The most effective work is associated with reducing the asymmetry of the relations, understood as the primacy of the position in relations: child, a parent and a team of therapists. The quality of work is also related to introducing a transdisciplinary model of cooperation in which both the child and the parent are not only the recipients, but also active and equal links in a team who take part in providing the diagnosis, directions of interaction, development program, and monitoring development progress. All team members take responsibility for the effects of cooperation $[1,2]$. That why a high level of involvement of all team members is assumed. Interactions are jointly established and programmed. Furthermore, cooperation and appropriate management of both the team and the therapy process are taught [3-5].

The very concept of the early introduction of therapeutic activities did not change its meaning over the years. What has changed was the target group to include care for all children at risk of or exhibiting developmental disorders, the access to services became easier, the possibility of receiving support was made independent from the material status of the family. In many European countries, Poland included, appropriate legislative changes were introduced in order to regulate the formal and legal state of the functioning of the system.

\section{The Need for Early Therapeutic Activities}

Previous research on the purposefulness of taking actions in the area of early intervention and supporting development of children clearly show that the time of taking up rehabilitation is of vital importance in further development of a child with disabilities and/or at risk for developmental deficits [6]. In the case of perceptual 
deficits - hearing or speech disorders - early detection, diagnosis and rehabilitation determine significantly higher level of development of verbal communication. Similarly, in the case of children who are deaf or hard of hearing, a far better use of hearing equipment determines much better developed language system. Performing different roles, undertaking various activities, the possibility of better social functioning are made possible by eliminating communication barriers [7-10]. Also in the case of different perceptual disorders, such as impaired vision or coupled multiple disabilities, early actions prevent the exclusion and the maintenance of sensory and cognitive functions prevents functional illiteracy. Thanks to raising awareness and compensating for deficits, cognitive and instrumental competences can be developed basing on other, undamaged senses. Achieving autonomy and independence is made possible [11-14]. In children with suspected or present intellectual disability, early stimulation allows for the minimizing of deficit (mental retardation) achieving the highest possible level of functioning through the use of development potential of a young child's brain for the creation of a specific "new" trajectory of development $[15,16]$.

The effectiveness of support depends on many factors, including the specificity of disability and/or deficit, and on personality predispositions. In the success of each entity, the role of a parents and involvement of all members of therapeutic team is significant. Achieving optimal development in biological, psychological and social spheres is determined by the implementation of adequate and intensive actions at the earliest possible stage of development $[17,18]$.

\section{Early Support System in Poland}

Even though the system of rehabilitation operates in Poland since the founding of the first special schools in 18 th century, it did not cover all children requiring support. Special education was dealt with the idea of early intervention was understood as taking immediate and appropriate actions of detecting, diagnosing and rehabilitating; however it was used only in children with a diagnosed disability. There was no institution involving children at risk for developmental problems, or those in which said issues occurred yet their specificity and severeness is different form disability.

Currently in Poland there are essentially two forms of early therapy - early childhood development support and early intervention. The aim of the former is to stimulate the psychomotor development of a child, whereas the latter aims at medical rehabilitation. Early intervention included children at risk of disability, and those with disabilities were taken care of by teams of early development support. However, the prevailing intricacies of legal nature and the existence of two definitions of disability (medical and pedagogical) also do not allow for a clear specification which of the forms of support (early development support/early intervention) should be used in the case of children with non-specific developmental problems and/or difficulties affecting their functioning now and in the future, yet not considered disability. Thus, early childhood development support and early intervention cannot be considered complementary $[19,20]$. These are actions covering children from the moment of the detection of a disability up to 7 years of age in the case of early intervention and up to school entry in the case of early development support. For school-age children rehabilitation activities are organized [21-23].

At present, in Poland the most popular and easily accessed facilities supporting a young child are teams of early childhood development support. The first guidelines for their organization and functioning can be found in legal regulations in the year 1991. Those were the basis for executive acts - regulations and ordinances on the organization of early childhood development support in $2005[24,25]$. Currently, the legal basis for the functioning of early development support system is the Ordinance of the Minister of National Education of 24 August 2017 [26], which is the executive act for the Education Act of 14 December 2016 [20]. The ordinance specifies that a team of early development support shall be appointed by the principal of an educational institution, including pre-schools and psychological and pedagogical counseling centers, or a legal entity being the manager of a facility of another form of pre-school education. The work of the team is supervised by a principal, coordinator, or a natural person in charge of other forms of pre-school education. Appointed team has to have teaching and infrastructure base adequate for conducting activities involving young children. The team consists of specialists who are authorized to provide therapy for children with specific developmental needs, in particular special education teachers, speech therapists, psychologists, etc. The team's task is to determine the level of functioning of a child and to designate the direction of activities, prepare and implement development support programs, monitor and implement changes in the programs on the basis of diagnosis and follow-up observation. In addition, the team is required to provide special support for the family, as well as to cooperate with entities such as social services and medical institutions. Family support shapes appropriate attitudes and behaviors, adapts to the disability and creates bonds and relationships between children and their parents/families. Team members provide instructions, advice, and consultation. Activities within the framework of early development support are organized as 4 to 8 hours per month. If needed, the number of hours can be increased. Activities are conducted individually with the child and their family; however there is also a possibility of group work, in which case the number of children cannot exceed 3. Activities can be conducted in the facility, or at home if the child is younger than 3 years old. Therapists in charge of activities in early development support are required, depending on their job, to have an MA degree in 
psychology, a BA and/or an MA degree in education or special education specializing in early development support, or a BA and/or an MA degree in physiotherapy, movement rehabilitation, and pedagogic therapy with pedagogical preparation. In the case of a degree in specialties other than early development support, qualifications must be supplemented in this regard or in other forms of therapy providing support for the psychomotor development of a young child. Teams can also employ speech therapists who are qualified to work as teachers.

Previous studies on the functioning of teams of early development support have shown that the system is growing rapidly and is becoming more and more accessible, free of charge and flexible. The biggest problems faced by the teams were connected with legal complexities and poor infrastructure stemming from weak financing of the activity. The following were identified as strong points:

- flexibility and availability of forms of support,

- short waiting time and commitment of therapists in the creation of maximum favorable support of families,

- $\quad$ targeted to work with the family and child in need of therapy,

- $\quad$ high level of determination, despite of the drastic limitations of money and increasing numbers of children in need of development support,

- flexibility/activity access.

Weak points of the system include:

- poorly functioning legal system that creates restrictions on jurisprudence,

- hours per child and forms of support,

- $\quad$ poor financing system, not retrofitting institutions aids to conduct therapy,

- $\quad$ poor infrastructure including the lack of space and equipment [27].

\section{Material and Method}

The aim of the research undertaken was to diagnose the Polish system of early childhood development support. The issue was limited to the functioning of teams of early development support; diagnosis of functioning of the teams according to the model multi, inter and transdisciplinary. There was taken into account specific of the relation in following areas:

- carrying out diagnosis,

- cooperation with parents,

- development of work program,

- responsibility for the realization of the program,

- means of communication within the team,

- content assumptions,

- team development,

- cooperation with other entities,

- $\quad$ selection of team members,

- directives for functioning [28].
Areas in which work differs from the generally prevailing model were determined, and the importance of a given situation for the quality of therapy was assessed. The directions of the changes ware scorched. Research was conducted in the post-positivist paradigm [20] using a quality-quantity strategy. The diagnostic survey method was used. The research was conducted individually with team representatives, coordinating and controlling the research process by the operator. The research was carried out using the paper-pencil method. For the purpose of the present work, a research tool was developed on the basis of Twardowski's models of teamwork (furthermore in subsection 4.1). The tool included a metric and a main part, in which the respondents were defining in 10 areas (by indicating one of the proposed terms) the most suitable way of cooperation for represented team (Appendix 1). The study was conducted in November - December 2016 in the southern Poland.

\subsection{The Theoretical Basis for Constructing of Research Tool}

Research has been design taking into consideration three models of the teams' functioning: multidisciplinary, interdisciplinary, transdisciplinary by Twardowski [28].

The first model is one in which each link functions independently of others, the members are autonomous in their decisions; they are not responsible for the operation of the entire team of early childhood development support, only for the realization and progress of their own work. In a team operating according to the multidisciplinary model, diagnosis is carried out separately by each of the members. Said member is also responsible for developing activities program on the basis of the diagnosis and according to their specialty. Specialists establish content assumptions, aims, tasks, principles of work in accordance with their disciplines. They perfect their skills and methods, as well as broaden knowledge in their specialties. Cooperation with a parent is informal, with a noticeable asymmetry of relation. Parent and child are not members of the team, but subjects of therapeutic activities. The main task of the parent is to provide the necessary information about the child, their needs, progress, etc. Parents do not agree on the program with the specialists. Their job is to implement part of the therapeutic tasks set by the specialists. Information flow in the team is informal, team meetings are rare and mostly the result of rules and obligations.

The operation of a team in an interdisciplinary model indeed brings the members closer, however, the responsibility for the diagnosis, design of the development support program and execution of tasks resulting from it still lies in individual subjects of the therapy. Services are offered in accordance with the therapist's qualifications; however individual consultations with other team members on the developed and conducted activities also occur. Team members are required to collect information on the course of the therapy as part of their interactions and those of other members. Exchange of information takes place in irregular 
meetings during which the so-called cases are consulted on. Common content assumptions are made. Aims, methods, measures, tasks, and policies are in accordance with one's discipline. Members broaden their knowledge and skills within their disciplines, and they also attempt to complement it with those from outside their specialties. Parents and children are not members of the team; however the asymmetry of relations is visibly reduced. Parents have more influence on the course of activities. Meetings with team members and/or representatives of the team are individual, usually formal. It happens that parents take part in team meetings consulting the progress of therapy.

According to the transdisciplinary model, a team works as one organism. Parents and the child are full members of the team. The parent is an active "specialist" engaged at all stages, the child is not a case or a subject of activities. Diagnosis is carried out jointly by all team members and on its basis a common program of activities is developed. The program takes into account not only the child, but their whole surrounding, the team included. Responsibility for the realization of the program, progress, constant diagnosis lies in all team members. In the face of a setback, no individual blame is placed as the team works as a whole. A unified program of activities crosses the boundaries of scientific disciplines. Information flow is constant; meetings are organized when such a need occurs. During those, a discussion takes place during which the directions for interactions, changes, etc. are jointly established. During the meeting, the members also undergo training, gain new experience, knowledge and skills, work on team cohesion and perfect teamwork. Members acquire and share their knowledge from different disciplines, including their primary specialization.

\subsection{Characteristics of the Sample}

44 team involved in early childhood development support took part in the research. They were located in the Lesser Poland, Silesian, Podkarpackie, Masovian, Pomeranian, and Lower Silesian Voivodeships. Representatives of teams (directors or team coordinators) answered questions for diagnosing the condition of the team and manner of operation. The units were represented by principals, team coordinators, and therapists. Teams studied work within the public sector and use designated subsidies from national budget funds for their operation. The teams under research included:

- $\quad$ very young teams - the period of activity under 3 years $(\mathrm{N}=5)$,

- $\quad$ the teams operating from 3 to 7 years $(\mathrm{N}=18)$,

- the teams operating for over 7 years $(\mathrm{N}=21)$.

Taking into account the number of permanent team members, 17 teams could be classified as very small, 13 as small, 8 as medium, 2 as big, and 4 as very big. When considering the size of teams in terms of the number of children under their care, 4 teams were classified as very small, 5 as small, 17 as medium, 10 as big, and 8 as very big (Table 1.).
Table 1. Summary of data on the size of team units due to variables: number of staff and number of pupils

\begin{tabular}{|c|r|c|c|}
\hline \multicolumn{2}{|c|}{ The size of the team } & $\begin{array}{c}\text { Due to the number of } \\
\text { personnel }(\mathrm{N}=44)\end{array}$ & $\begin{array}{c}\text { Due to the number } \\
\text { of pupils (N =44) }\end{array}$ \\
\hline very small & $\leq 10$ & 17 & 4 \\
\hline small & $11-19$ & 13 & 5 \\
\hline medium & $20-29$ & 8 & 17 \\
\hline big & $30-39$ & 2 & 10 \\
\hline very big & $\geq 40$ & 4 & 8 \\
\hline
\end{tabular}

\subsection{Results of Own Research}

The studies provide very important information on the functioning of the early development support teams. Based on the results of researches, it may be presumed that global functioning of early development support teams is not subject to a single model. Depending on the area, there are mixed strategies of the cooperative model of multi, inter and transdisciplinary. Research results show that in the area of diagnosis, the interdisciplinary model prevails $(45.5 \%$ of facilities). The diagnosis in most facilities is carried out individually by each specialist and then consulted. The activities keeping the key actions for the design of further interaction is entrusted to the person skilled, taking into account the multidimensional overview. Interdisciplinary also prevails in cooperation with parents $(40.9 \%)$. A parent is not a full member of the team, but does participate in the execution of tasks. Participation is characterized by an asymmetry of relations. The role of the parent is also marginalized and reduced to provide information, without the possibility of discussion and confrontation. The role of the parent in the team is also confirmed in the analysis of other areas. In more than $40 \%$ of institutions working with parent runs also under a multidisciplinary model, which means that he or she is not a full-fledged member of the team, and the only consultant providing information about the child. The activities here are, however, more centralized and maintained the flow of information about a child in a team protects the parent from taking feature called "courier", it is a person who not only provides information about the child from the family environment, but also is a kind of link between cell team that conveys information from therapists among themselves. Development and implementation of therapy programs is a balance of work in interdisciplinary and transdisciplinary model $(47.7 \%$ each), therefore the program is developed by specialists with parent participation. The program of early development support in the same number of units is determined jointly by all team members and parents or any specialist prepares its own program of work, which is then consulted in the team. However, confronting the preparation of the program and its realization, it is noted that in most cases specialist is responsible for own specialization module, which means that activities in the field of determining the program and its implementation will only accept a seemingly multi or transdisciplinary model $(38.6 \%)$. Team communication occurs as in the interdisciplinary model $(54.5 \%)$. Communication in most 
teams is informal, exchange of experience and information takes place irregularly, usually takes the form of case studies during team meetings. It should be noted, however, that in large number of cases the effort is made to perform the team members meetings an informative-training character, serving the good of pupils. In many cases the information provider notices and calling for change in the nature of cooperation and exchange of information. Content assumptions are made in accordance with the transdisciplinary model (52.3\%), in which teams members adopt common assumptions crossing the boundaries of specialties in order to realize a unified program. The assumption is substantively beyond its own specialization of team members. It is taken into account the specifics of multi-faceted operation to support development. Improving therapists is not only serving to deepen knowledge on their own specialties, but also involves the acquisition and raise awareness on the related fields and / or aimed at developing a better working method. In the case of team development, a balance between interdisciplinary and transdisciplinary model is observed $(45.5 \%$ each). This means that attempts are made at development both within one's domain and broadening knowledge in needed areas in the case of the interdisciplinary model, and broadening one's knowledge and skills by diving into various disciplines in the transdisciplinary model. Cooperation with other entities is irregular, short-time, in accordance with the multidisciplinary model (61.4\%). Research shows that cooperation is unsystematic, unplanned, takes place in the event of need. Representatives of other actors that support the development, including counseling, social care centers and others - these entities, despite the real needs are not identified as members of teams. It is also difficult for normal relations, common satisfactory co-operation, compliance and respect for each other, when in most institutions team building is dictated by law, and not real needs. Critical to the work of the team seem to be information regarding the selection of members and the nature of the relationship prevailing in teams. Undoubtedly, the provided information exposes and identifies the weaknesses of cooperation not only within the team, but also with other entities in the operating environment. Team selection is done by a leader, and it is compatible with the qualification of the personnel (multidisciplinary model $40.9 \%$ ). Managing a team is dictated by strict rules and law; it does not result from the personality, character, and temperament of members (93.2\%) (Table 2, Figure 1).

Taking into account the results of researches, Polish model of early support of child development can be described as:

1. Carrying out diagnosis: Diagnosis is carried out jointly by a team of specialists (without parents);

2. Cooperation with parents: Parents meet individually with team members or a team's representative, they are sometimes invited to team meetings;
3. Development of work program: Team members develop their own separate programs and consult them together or Team members and parents jointly develop program of work with a child taking into account the specificity of child's development and the family;

4. Responsibility for the realization of the program: Team members are responsible for realizing their "section" of the program or a separate program;

5. Means of communication within the team: Team meeting are held, they mostly focus on the analysis of the so-called case;

6. Content assumptions: Team members adopt the most important assumptions specific to their own specialty;

7. Team development: Team members develop mainly within their specialization but broaden their knowledge and skills on the basis of what is useful from other disciplines or Team members broaden their knowledge and skills on the basis of various disciplines;

8. Cooperation with other entities: If need be, team members cooperate with other entities (e.g. social services);

9. Selection of team members: Team is selected in accordance with the qualifications of the personnel, the leader selects;

10. Directives for functioning: Functioning of the team is dictated by the legal/statutory regulations.

The simple definition of the dominant model of cooperation, according to Twardowski' models, is very difficult. Taking into account the examined component areas, it is simply to find the solutions characteristic for multi, inter and transdisciplinary models, in different proportion. More important than the model as itself, it seems to determine the weaknesses of the functioning of the teams, basing on it. For this purpose, the European Agency for Development in Special Needs Education report has been used [1]. It includes guidelines, which guarantee the effectiveness of assistance, depending on the quality and functioning of the system and teams that build this structure. The differences between Polish teams work and the European trends mostly manifest in 4 main areas. These are shortcomings such as: cooperation of subjects; inclusion of parents into the work of team, including parents' rights; equal of entities; communication. The members of the team cooperate incomplete, parents do not receive full rights as the members, and they've got arbitral position in team. The model diagnoses disruptions of flow and information exchange. A significant majority of the teams do not cooperate with other entities, which providing support services, for example, social assistance. Difficulties may be provided also by the lack of flexibility in the way of selecting members and the functioning dictated by the law regulations, without the proper interpretation. 
Table 2. Research results on the implemented model of work in diagnosed area of functioning of the early development support team.

\begin{tabular}{|c|c|c|c|c|c|c|c|c|c|c|c|c|c|c|c|c|c|c|c|c|}
\hline \multirow{2}{*}{$\begin{array}{c}\text { Implemented } \\
\text { model }\end{array}$} & \multicolumn{2}{|c|}{$\begin{array}{l}\text { Carrying out } \\
\text { diagnosis }\end{array}$} & \multicolumn{2}{|c|}{$\begin{array}{l}\text { Cooperation with } \\
\text { parents }\end{array}$} & \multicolumn{2}{|c|}{$\begin{array}{l}\text { Development of } \\
\text { work program }\end{array}$} & \multicolumn{2}{|c|}{$\begin{array}{l}\text { Responsibility for the } \\
\text { realization of the program }\end{array}$} & \multicolumn{2}{|c|}{$\begin{array}{c}\text { Means of communication } \\
\text { within the team }\end{array}$} & \multicolumn{2}{|c|}{$\begin{array}{c}\text { Content } \\
\text { assumptions }\end{array}$} & \multicolumn{2}{|c|}{$\begin{array}{c}\text { Team } \\
\text { development }\end{array}$} & \multicolumn{2}{|c|}{$\begin{array}{c}\text { Cooperation with } \\
\text { other entities }\end{array}$} & \multicolumn{2}{|c|}{\begin{tabular}{|c|} 
Selection of \\
team members
\end{tabular}} & \multicolumn{2}{|c|}{\begin{tabular}{|c|} 
Directives for \\
functioning
\end{tabular}} \\
\hline & $\mathrm{N}$ & $\%$ & $\mathrm{~N}$ & $\%$ & $\mathrm{~N}$ & $\%$ & $\mathrm{~N}$ & $\%$ & $\mathrm{~N}$ & $\%$ & $\mathrm{~N}$ & $\%$ & $\mathrm{~N}$ & $\%$ & $\mathrm{~N}$ & $\%$ & $\mathrm{~N}$ & $\%$ & $\mathrm{~N}$ & $\%$ \\
\hline Multidisciplinary & 10 & 22,7 & 13 & 29,5 & 2 & 4,5 & 17 & 38,6 & 7 & 15,9 & 6 & 13,6 & 4 & 9,1 & 27 & 61,4 & 18 & 40,9 & 41 & 93,2 \\
\hline Interdisciplinary & 20 & 45,5 & 18 & 40,9 & 21 & 47,7 & 14 & 31,8 & 24 & 54,5 & 15 & 34,1 & 20 & 45,5 & 16 & 36,4 & 14 & 31,8 & 3 & 6,8 \\
\hline Transdisciplinary & 14 & 31,8 & 13 & 29,5 & 21 & 47,7 & 13 & 29,5 & 13 & 29,5 & 23 & 52,3 & 20 & 45,5 & 1 & 2,3 & 12 & 27,3 & 0 & 0 \\
\hline
\end{tabular}

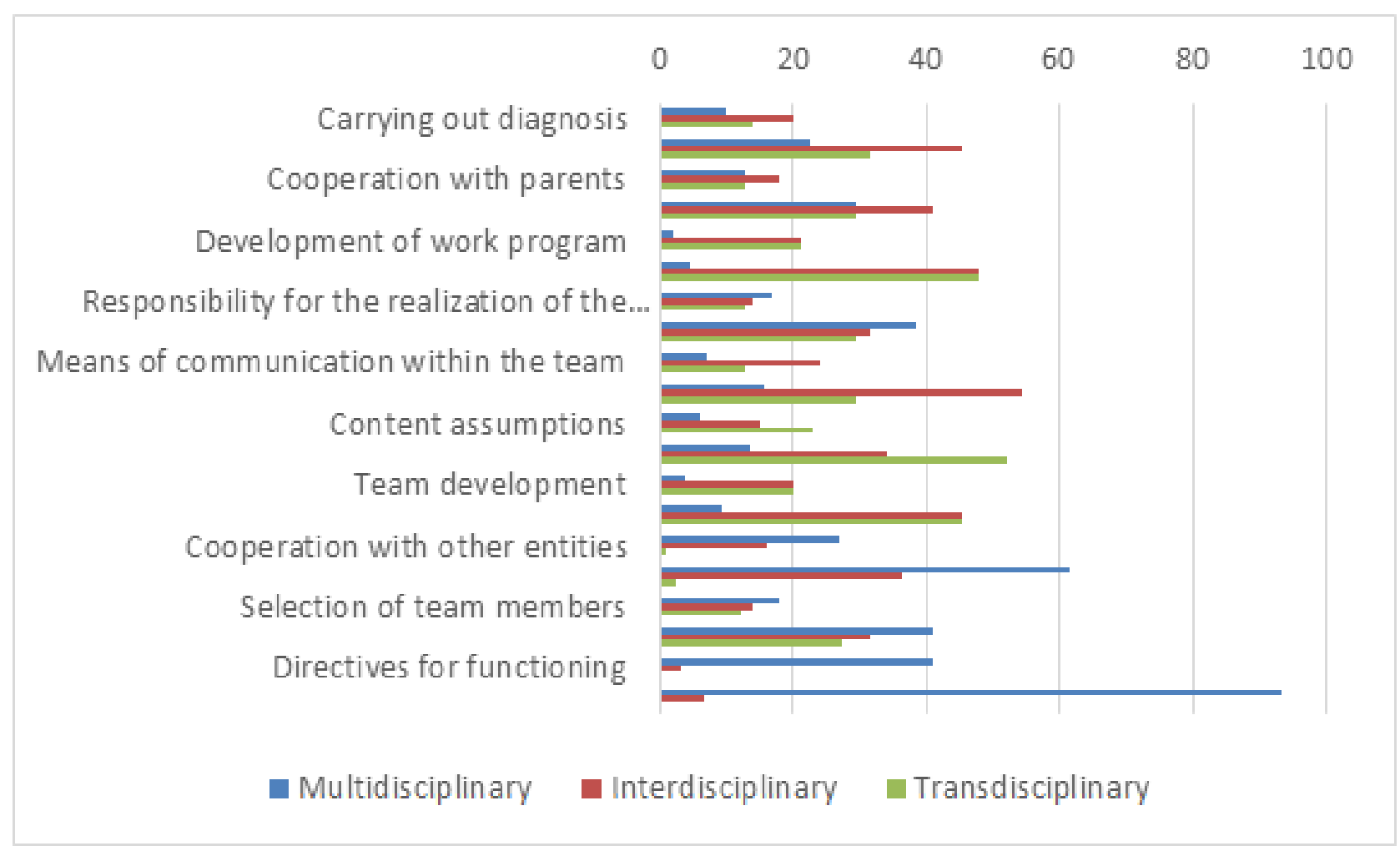

Figure 1. Graphical presentation of research results on the implemented model of work in diagnosed area of functioning of the early development support team (raw results and recalculate results in \%). 


\section{Discussion of the Results}

Despite of many years of tradition of organizing of rehabilitation for disabled children in Poland, the work of early development support teams is the first of such a wide range of activities. It reaches the majority of special care children and breaks the barriers of unavailability. Teams provide services in educational institutions, as close as possible of children and their families' place of residence. They break the limitation of distances, time, and finances. They work dynamically, and develop themselves, but not without mistakes to avoid. Researches expose the dilemmas of functioning of development support teams. They are strongly associated with the diagnosed model of teamwork.

The reasons for the situation, it seems, can be found in historical conditions, changes which relatively young teams are subject to, develop their own identity, and the legislative situation. The past influences, as the first factors, are mostly exemplified in the team's relations and communication. The dominance here is: the asymmetry of the relations of team members and parents with child, the hierarchical system of power in the team, the specific selection of members and management of team. Another factor is the time of teams' operation; as young and developing institutions are looking for their own way of functioning. They work on solutions adequate to the Polish reality but based on international trends. Next reason may lie in legal regulations and difficulties, resulting from the application of imposed solutions, which are often unsuitable for the needs of teams.

There is the question, what influence on the quality of therapy has such model of functioning of the teams. Basing on own research, it can be presumed, that it's a formation well adapted to the conditions prevailing in a given place and time. The number of supported children and their families, the effects of therapy, reported satisfaction of parents, seems to confirm the effectiveness of teams' work. Identified difficulties or shortcomings seem to be compensated by the level of knowledge and skills of therapists, the degree of their involvement and willingness of develop. However, referring to the models of team functioning, the most effective work is consistent with the transdisciplinary model. This model treating the team as an integer, one organism, submitting collective work over an individual, eliminates divisions, assumes co-dependence for team work. It assumes the equivalence and validity of all entities implicit in the system of supporting favors. Team communication is without barriers, it is one of the most important elements of cooperation. All European institutions strive to work according to the transdisciplinary model. Polish teams also have to strive for this kind of cooperation $[1,28]$. Critical for this case seems to be the improvement of the functioning in the indicated areas.

\section{Conclusions}

The present research is one of the first in Poland, regarding relatively young "institutions" such as early development support teams. This calls for observing the direction of changes in cooperation of teams, much so that the latest ordinance of the Minister of National Education, as it were, facilitates the creation of new teams, broadens the list of qualifications giving ground to employment in teams which, on the one hand increases the availability and possibility of caring for a greater number of children, on the other hand however, poses real threat to the quality of functioning of the system, the lack of control over the teams' operations.

Research results provide an answer to the question of the model of work. It is a specific model of functioning of teams, devoted to Polish reality, according to which teams of early development support operate. The fact is, however, that the analysis allows for the discovery of weaknesses and strengths. The most serious dilemma in the teams' work seems to be the cooperation with parents. On the one hand, their role is not questioned; on the other hand, they are not made equal members. It can be said that the attitude towards them defines the work of the whole team. In the transdisciplinary model, the parent is an equal member of the team and is just as responsible for its development, content assumptions, communication, etc. For example, by eliminating parents from the cooperation, the work is only pseudo-realizing the assumptions of the transdisciplinary model.

\section{Appendix 1}

\section{Research Tool}

Dear Sirs,

Please respond to the following statements by choosing the one that best describes the way your team of early development support team works:

Diagnosis:

Each team member carries out their own diagnosis

Diagnosis is carried out jointly by a team of specialists

Diagnosis is carried out jointly by a team of specialists and parents/guardians.

Participation of parents:

Parents meet individually with team members

Parents meet individually with team members or a team's representative, they are sometimes invited to team meetings

Parents are full and active members of the team, they always participate in all activities/procedures 
Development of program of work with a child:

Each team members develops their own separate program according to their specialty

Team members develop their own separate programs and consult them together

$\square$ Team members and parents jointly develop program of work with a child taking into account the specificity of child's development and the family

Responsibility for the realization of the program:

Team members are responsible for realizing their "section" of the program or a separate program

$\square$ Team members are responsible for gathering information on the realization of their "section" of the program or a separate program and other members" "sections".

Each team member is responsible for the implementation and realization of programs by all team members.

Means of communication:

There is an informal exchange of information

Team meeting are held, they mostly focus on the analysis of the so-called case

Team meetings are held regularly, they focus on the exchange of information, substantive improvement and acquisition of skills

Content assumptions:

Team members adopt the most important assumptions specific to their own specialty

$\square$ Team members adopt as the most important those assumptions that are part of the general program of the team

$\square$ Team members adopt common assumptions crossing the boundaries of specialties in order to realize a unified program

Team development:

Team members develop mainly within their specialization

Team members develop mainly within their specialization but broaden their knowledge and skills on the basis of what is useful from other disciplines

$\square$ Team members broaden their knowledge and skills on the basis of various disciplines

Cooperation with other entities:

If need be, team members cooperate with other entities (e.g. social services)

Team members stay in touch with other entities

Representatives of other institutions are permanent members of teams
Selection of team members:

Team is selected in accordance with the qualifications of the personnel, the leader selects

$\square$ Team is selected in accordance with the qualifications of the personnel taking into account the needs and suggestions of a family, the leader selects

Team is selected in accordance with the qualifications of the personnel taking into account the needs and suggestions of a family, choice is made as a result of joint decision/discussion

Functioning:

Functioning of the team is dictated by the legal/statutory regulations

$\square$ Functioning of the team results from the personality, character, and temperament of the members

\section{Demographics:}

- $\quad$ Person providing information (workplace):

- Place of operation of the facility:

- Service locations:

- Number of staff employed:

- Number of pupils:

- The period of operation of the facility:

\section{REFERENCES}

[1] European Agency for Development in Special Needs Education. Early Childhood Intervention Analysis of Situations in Europe: Key aspects and recommendations. Belgium - Denmark. 2005.

[2] C.T., Ramey, S. L. Ramey. Early intervention and early experience. American Psychologist, Vol.53, No.2, 109-120, 1998.

[3] M. Berryman, P. Woller. Early Intervention Services: Effectively Supporting Māori Children and Their Families Weaving educational threads. Weaving educational practice. Vol.12 No.1, 2011, 3-9.

[4] S. Jerger, R. J. Roeser, E. A. Tobey. Management of Hearing Loss in Infants: The UTD/Callier Center Position Statement, Journal of the American Academy of Audiology, Vol. 12, 329-336, 2001.

[5] D. Chen, M. Haney. An Early Intervention Model for Infants Who Are Deaf-Blind. Journal of Visual Impairment \& Blindness, Vol. 98, No. 3, 213-121, 1995.

[6] World Health Organization. Early childhood development and disability: discussion paper. WHO Library, 2012.

[7] M.P. Moeller. Early Intervention and Language Development in Children Who Are Deaf and Hard of Hearing, Pediatrics, Vol.106, e43, 2000, Online available from http://www.pediatrics.org/cgi/content/full/106/3/e43 
[8] R. Calderon, J. Bargones, S. Sidman. Characteristics of hearing families and their young deaf and hard of hearing children: early intervention, American Annals of the Deaf, Vol.143, 347-362, 1998.

[9] A. Kuenburg, P. Fellinger, J. Fellinger. Health care access among Deaf people. Journal of Deaf Studies and Deaf Education Vol. 21, 1-10, 2016.

[10] C.R. Kennedy, D. C. McCann, M. J. Campbell, C. M. Law, M. Mullee, S. Petrou, P. Watkin, S. Worsfold, H. M. Yuen, J. Stevenson. Language Ability after Early Detection of Permanent Childhood Hearing Impairment, The New England Journal of Medicine, Vol. 354, 2131-2141, 2006.

[11] V. E. Bishop. Teaching visually impaired children. Springfield, IL: Charles C Thomas, 1996.

[12] D. Kobal Grum, B. Kobal. Early Intervention of the Blind and Visually Impaired Children and Their Families: A Slovenian Case, Hrvatska Revija za Rehabilitacijska Istraživanja, Vol.46 No.2 116-127, 2010.

[13] Michael, M., Paul, P. Early intervention for infants with deaf-blindness. Exceptional Children, Vol. 57, No.3, 200-210, 1991.

[14] N. Dale, A. Salt. Early support developmental journal for children with visual impairment: the case for a new developmental framework for early intervention. Child: Care Health and Development,. Vol. 33, No. 6, 684-690, 2007.

[15] A. Majnemer. Benefits of Early Intervention for Children With Developmental Disabilities. Seminars in Pediatric Neurology, Vol. 5, No. 1, 62-69 1998.

[16] M.J. Guralnick. Early Intervention for Children with Intellectual Disabilities: Current Knowledge and Future Prospects, Journal of Applied Research in Intellectual Disabilities, Vol.18, 313-324, 2005.

[17] G. Mahoney, B. Wiggers. The Role of Parents in Early Intervention: Implications for Social Work. Children \& schools, Vol.29, No.1, 7-15, 2007.

[18] M. Hadders - Algra. Challenges and limitations in early intervention, Developmental Medicine and Child Neurology. Vol. 53, I. 4, 52-55, 2011.
[19] Rozporządzenie Ministra Edukacji Narodowej z dnia 5 września 2017 r. $\quad$ w sprawie szczegółowych zadań wiodących ośrodków koordynacyjno rehabilitacyjno-opiekuńczych (Dz. U. z 2017 r. Poz. 1712)

[20] Ustawa Prawo oświatowe z dnia 14 grudnia 2016 (Dz. U. z 2017 r. Poz. 59)

[21] Rozporzadzenie Ministra Edukacji Narodowej z 28 marca 2017 r. w sprawie ramowych planów nauczania dla publicznych szkół (Dz.U. z 2017 r. poz. 703)

[22] Rozporządzenie Ministra Edukacji Narodowej z dnia 9 sierpnia 2017 r. W sprawie warunków organizowania kształcenia, wychowania i opieki dla dzieci i młodzieży niepełnosprawnych, niedostosowanych społecznie i zagrożonych niedostosowaniem społecznym (Dz. U. z 2017 r. Poz. 1578)

[23] Rozporządzenie Ministra Edukacji Narodowej z 17 marca 2017 r. w sprawie szczegółowej organizacji publicznych szkół i publicznych przedszkoli (Dz.U. z 2017 r. poz. 649)

[24] Rozporządzenie Ministra Edukacji Narodowej i Sportu z dnia 4 kwietnia 2005 r. w sprawie organizowania wczesnego wspomagania rozwoju dzieci (Dz. U. z 2005 r. Poz. 587)

[25] Rozporządzenie Ministra Edukacji Narodowej z dnia 11 października 2013 r. w sprawie organizowania wczesnego wspomagania rozwoju dzieci (Dz. U. z 2017 r. Poz. 1257)

[26] Rozporządzenie Ministra Edukacji Narodowej z dnia 24 sierpnia 2017 r. w sprawie organizowania wczesnego wspomagania rozwoju dzieci (Dz. U. z 2017 r. Poz.1635)

[27] A. Czyż. Early Support Development of Children with Disorders of the Biopsychosocial Functioning in Poland, In: Current business and economics driven discourse and education: perspectives from around the world, (Eds. N. Popov, Ch. Wolhuter, J. Kalin, G. Hilton, J. Ogunleye, E. Niemczyk, O. Chigisheva, BCES Conference Books, Vol.15, 209-216, 2017.

[28] A. Twardowski. Wczesne wspomaganie rozwoju dzieci z niepełnosprawnościami w środowisku rodzinnym. Poznań, 2012.

[29] J. W. Creswell. Qualitative, Quantitative and Mixed Methods Approaches. 2nd edn. London: Sage; 2003. 